\title{
Antifungal properties of selected plants of Apocynaceae family against the human fungal pathogen Candida albicans
}

\author{
Savita Bajrang Wankhede, Madhushree Madhumita Routh, Sandeep Balsingh Rajput, *Sankuny Mohan Karuppayil \\ DST-FIST and UGC-SAP Sponsored School of Life Sciences, SRTM University, Nanded 431-606, M.S, India
}

\begin{abstract}
The ethnobotanical evaluation of plant based chemicals has proven themselves greatly in last few decades. Plants have been a rich source of therapeutic agents and form the basis of traditional medicine system. On the basis of this, in vitro antifungal activities of extracts of Catharanthus roseus, Nerium oleander and Taberenemontana divaricata leaf extracts were evaluated in the present study by 96 well microtiter plate assays using human fungal pathogen Candida albicans ATCC90028 strain. The activity was measured by spectophotometric methods to determine the Minimum Inhibitory Concentration (MIC). The Minimum Fungicidal Concentrations (MFC) for the extracts was also determined by a plate assay. The distilled water extract, petroleum ether extract, methanolic extract, ethyl acetate extract and sequential distilled water leaf extracts of all the plants showed potential activity against C. albicans ATCC 90028. The study ascertains the value of Apocynaceae plants, which could be of considerable interest to the development of new safer antifungals.
\end{abstract}

Key Words: Catharanthus roseus, Nerium oleander, Taberenemontana divaricata, antifungal, Candida albicans.

\section{INTRODUCTION}

Plant use in treating diseases is as old ashuman civilization and traditional medicines are still a major part of regular treatments of different maladies (Alviano and Alviano, 2009). Plants are no doubt one of the main sources of biologically active materials. According to a recent report medicinal herbs are used by $80 \%$ of world population living in rural areas for their primary healthcare (Sakarkar and Deshmukh, 2011). In Europe and USA $50 \%$ of the prescriptions are prescribing natural products including plants or their derivatives for different maladies (Cordell, 2002; Newman et al., 2007). Interestingly out of the $250,000-500,000$ plant species on earth, only $1-10 \%$ have been studied chemically and pharmacologically for their innumerable medicinal values (Verpoorte, 2000).

Recently the synthetic chemistry has dominated the market of drug discovery and production still there is enormous scope for bioactive principles or extracts derived from plants (Raskin et al., 2002). If we compare them with synthetic drugs than plant derived natural products are surely good source of biologically active agents since they are natural and cost effective (Ghosh et al., 2008). Again plant molecules may have different mode of action than conventional drugs derived agents may have different mechanisms than conventional drugs so as they may be better for health care improvement (Eloff et al., 1998). Plant derived natural products are generally bioactive secondary metabolites with better potential to treat different diseases. Some examples of these compounds include terpenoids, alkaloids, phenols, unsaturated lactones, phenolic glycosides, saponins, sulphur compounds, cyanogenic glycosides and glucosinolates (Mukherjee et al., 2001; Quiroga et al., 2001). These plant based natural products are recently of interest among many scientists to design new remedies for different afflictions like microbial infections.

\footnotetext{
*Corresponding Author:

Dr. Sankuny Mohan Karuppayil, Professor

School of Life Sciences

SRTM University, Nanded, MS

India, 431606

E-mail: prof.karuppayil@gmail.com

Contact No.: +919028528438
}

During the last two decades scientists have tried to develop antimicrobial drugs with low side effects from the natural sources and it may be due to the increasing development of drug resistance to human pathogenic organisms. Candida albicans is a human fungal pathogen which causes severe infections in cancer, HIV AIDS, diabetic, surgery and organ transplantation patients. In the present study we have evaluated the in vitro antifungal properties of the plants from Apocynaceae family described below:

Catharanthus roseus is an important medicinal plant of family Apocynaceae. It is cultivated mainly for its alkaloids, which are having anticancer activities (Jaleel et al., 2009, Aslam et al., 2010). Antibacterial potential of crude extracts of different parts (viz., leaves, stem, root and flower) of Catharanthus roseus against clinically significant bacterial strains is also reported. The present investigation is focused on the screening of leaf extracts of Catharanthus roseus for antifungal activity.

Nerium oleander Linn. is a member belonging to Apocynaceae family. It is a herb with different colored flowers and is suited for dry locality (Lokesh et al. 2010). A wide spectrum of biological activities has been reported with various constituents isolated from different parts of the plant. Nerium oleander Linn. has been reported in ancient texts and folklore for many years and most of its parts and plant products such as flowers, leaves, leaf juice, latex and bark are used for the treatment of microbial diseases. Used traditionally by herbalists as a folk remedy for a wide variety of conditions, including dermatitis, abscesses, eczema, psoriasis, sores, warts, corns, ringworm, scabies, herpes, skin cancer, asthma, dysmenorrheal, epilepsy, malaria, abortifacients, heart tonics, leprosy and tumors (Singhal et al., 2011; Santhi et al., 2011).

Tabernaemontana divaricata (Family-Apocynaceae) is a beautiful evergreen shrub, about $54 \mathrm{~cm}$ high, with large shiny leaves, crepe jasmine flowers, may appear sporadically all year. T. divaricata, a garden plant in tropical countries, is a rich source of alkaloids with various 
pharmacological properties. It has been used in the folk medicine for anti-infection, anti-inflammation, analgesic, anti-tumour, antioxidative and for neurological disorders (Rumjhum et al., 2012; Pratchayasakul et al., 2008). In this study, the antifungal properties of leaf extracts are being reported to validate the traditional use of the crude drug through in vitro evaluation.

Global attention has been shifted towards finding new chemicals, specific the development of new drugs. These natural products can provide unique elements of molecular diversity and biological functionality, which is indispensable for novel drug discovery. The present investigation is focused on the screening of leaf extracts of Catharathus roseus, Nerium oleander and Tabernemontana divaricata for its in vitro antifungal activity against human fungal pathogen Candida albicans.

\section{MATERIALS AND METHODS}

\section{Cultures}

One standard strain of Candida albicans ATCC 90028, was obtained from Microbial Type Culture Collection (MTCC), Institute of Microbial Technology (IMTECH), Chandigarh, India, and maintained on yeast peptone dextrose (YPD) agar slants at $4^{\circ} \mathrm{C}$.

\section{Medium and culture condition}

Activation of culture was done by inoculating a single colony from YPD agar plate (yeast extract $1 \%$, peptone $2 \%$, dextrose $2 \%$, agar $2 \%$ ) into $50 \mathrm{ml} \mathrm{YPD} \mathrm{broth} \mathrm{in} \mathrm{a} 250$ $\mathrm{ml}$ conical flask. The flask was incubated at $30^{\circ} \mathrm{C}$ at 100 rpm on an orbital shaking incubator for $24 \mathrm{~h}$. Cells were harvested by centrifugation at $2000 \times \mathrm{g}$ and washed thrice with $0.1 \mathrm{M}$ phosphate buffer saline (PBS), $\mathrm{pH}$ 7.4. The cell density was determined by hemocytometer count; cells were suspended in PBS and used as inoculum for further experiments. All the media components and chemicals were purchased from HiMedia laboratories Pvt. Ltd. Mumbai, India. Fluconazole (Forcan) was purchased from, Cipla Pharmaceutical Ltd., India.

\section{Collection of plant materials}

Fresh and mature leaves of $C$. roseus, $N$. oleander and $T$. divaricata were collected from Nanded District in the state of Maharashtra (India). The medicinal plants were collected and identified according to their habit, habitat and floral characteristics following the guidelines described in Flora of Marathwada (Naik, 1998). The leaves of were shade-dried and powdered. The powder was sieved and stored in airtight containers. The botanical identity of the plant was confirmed at the School of Life Sciences of SRTM University, Nanded and herbariums are deposited in Lab no 7 of this department.

\section{Solvent extraction of plant materials}

10-20 g powder of the leaves was used for extraction. Extraction of leaves with distilled water was carried out at $100^{\circ} \mathrm{C}$ for $2-3 \mathrm{hrs}$ using a Borosil soxhlet apparatus, model 3840024. Extracts were filtered, evaporated, weighed, and re-dissolved in minimum volume of Methanol and used as a crude extract (Khan et al., 2011).

About $20 \mathrm{~g}$ powder of the leaves of $C$. roseus was sequentially extracted insolvents with increasing polarity viz. Petroleum ether $>$ Ethyl acetate $>$ Methanol and distilled water at their boiling temperature using Soxhlet's apparatus, for 2-3 hrs. Extracts were filtered, and evaporated; weights were taken and re-suspended in minimum quantity of Methanol. Concentrations of the stock solutions were adjusted to $100 \mathrm{mg} / \mathrm{ml}$.

\section{Drug susceptibility}

\section{Minimum inhibitory concentration (MIC)}

The susceptibility study was carried out by the standard methodology M 27 A2 as per CLSI guidelines (Pfaller et al., 2006). Briefly, various concentrations of the anticancer drugs were prepared in RPMI-1640 medium by double dilution in the 96 well plates. Each well contained an inoculum of $1 \times 10^{3}$ cells per $\mathrm{ml}$ and the final volume of RPMI-1640 medium maintained in each well was $200 \mu \mathrm{l}$. The wells without addition of drugs served as a control. Microplates were incubated at $35^{\circ} \mathrm{C}$ for 48 hours and read spectrophotometrically at $620 \mathrm{~nm}$ using microplate reader (Multiskan EX, Thermo Electron Corp. USA). The lowest concentration of the drugs which caused fifty percentage reduction in the absorbance compared to that of control was considered as MIC. Similarly, the fluconazole sensitivity of the two standard strains was determined. The activities of the drugs were compared to that of the standard antifungal drug fluconazole.

\section{Minimum fungicidal concentration (MFC)}

To determine the minimum Candida-cidal concentrations of the drugs, cells from MIC and the wells above that were selected. An aliquot of $10 \mu \mathrm{l}$ cell suspension from each well was spread on YPD agar plates. The plates were incubated for 24 hours at $30^{\circ} \mathrm{C}$ temperature and observed for presence of colonies. Absence of visual growth (no appearance of colonies) was considered as fungicidal concentration of the drug (Routh et al., 2011).

\section{Statistical analysis}

Values mentioned are the mean of triplicate observations with standard deviations indicated in parenthesis.

\section{RESULTS}

Effect of Catharanthus roseus (pink flower) extracts

Among the five extracts tested, petroleum ether and sequential distilled water extract of Catharanthus roseus leaf was found to be most effective growth inhibitors of $C$. albicans, inhibiting growth at $1 \mathrm{mg} / \mathrm{ml}$. The minimum inhibitory concentration for distilled water extract of leaf was $2 \mathrm{mg} / \mathrm{ml}$, whereas methanolic extract of leaf and ethyl acetate extract of leaf was $4 \mathrm{mg} / \mathrm{ml}$. Petroleum ether extract was the most efficient Candida-cidal, $8 \mathrm{mg} / \mathrm{ml}$ of it caused killing of all the cells. MFC of distilled water extract of leaf was at $16 \mathrm{mg} / \mathrm{ml}$, whereas sequential distilled water extract, methanolic extract and ethylacetate extract were not fungicidal up to $16 \mathrm{mg} / \mathrm{ml}$ concentration (Table 1).

\section{Effect of Catharanthus roseus (white flower) extracts}

The various leaf extracts of $C$. roseus leaf inhibited growth of $C$. albicans in a concentration dependent manner, in the range 0.25 to $4 \mathrm{mg} / \mathrm{ml}$. Methanolic extract of leaf was the most potent with MIC at $1 \mathrm{mg} / \mathrm{ml}$, followed by distilled water extract, ethyl acetate extract, petroleum ether and sequential distilled water extract having MIC at $2 \mathrm{mg} / \mathrm{ml}$ concentration. Among the five extracts tested, petroleum ether had the most cidal and killed Candida cells at $8 \mathrm{mg} / \mathrm{ml}$. Methanolic leaf extract exhibited MFC at $16 \mathrm{mg} / \mathrm{ml}$ concentration, whereas no MFC could be achieved for Distilled water extract, ethyl acetate extract and sequential distilled water extract up to $16 \mathrm{mg} / \mathrm{ml}$ concentration (Table 1).

\section{Effect of Nerium oleander extract}

Ethyl acetate extract of leaf was the most efficient agent with MIC of $1 \mathrm{mg} / \mathrm{ml}$. At the concentrations of $2 \mathrm{mg} / \mathrm{ml}$, these drugs showed more than $80 \%$ inhibition of growth. 
Distilled water extract and methanolic leaf extract exhibited MIC at $2 \mathrm{mg} / \mathrm{ml}$, whereas petroleum ether and sequential distilled water extract were comparatively less efficient with MICs of $4 \mathrm{mg} / \mathrm{ml}$. Efficient fungicidal activity was exerted by methanolic leaf extract at $8 \mathrm{mg} / \mathrm{ml}$. Ethyl acetate extract showed MFC at $16 \mathrm{mg} / \mathrm{ml}$. Among the others, distilled water extract and sequential distilled required $16 \mathrm{mg} / \mathrm{ml}$ concentrations for Candida- cidal effect. No MFC could be achieved up to $16 \mathrm{mg} / \mathrm{ml}$ concentration for petroleum ether extract (Table 1).

\section{Effect of Tabernemontana divaricata extract}

Ethyl acetate extract of leaf exhibited MIC of $1 \mathrm{mg} / \mathrm{ml}$ against growth of $C$. albicans 90028 . In this strain, $8 \mathrm{mg} / \mathrm{ml}$ of ethyl acetate was potent enough to kill all the cells. Distilled water extract, petroleum ether extract and methanol extract inhibited growth at $2 \mathrm{mg} / \mathrm{ml}$ concentration in the strain 90028; however it did not possess fungicidal activity against C. albicans up to $16 \mathrm{mg} / \mathrm{ml}$. To inhibit the growth of $C$. albicans 90028 , sequential distilled water extract required concentrations of $4 \mathrm{mg} / \mathrm{ml}$. Candidacidal activity was evident at $16 \mathrm{mg} / \mathrm{ml}$ for sequential distilled water extract of $T$. divaricata plant (Table 1 ).

\section{DISCUSSION}

Plants are important sources of potentially useful structures for the development of new drugs. Many reports are available on the antiviral, anticancer, antibacterial, antifungal, antihelmintic, antimolluscal and antiinflammatory properties of plants. Some of these observations have helped in identifying the active principle responsible for such activities and in the developing drugs for the therapeutic use (Ithart et al., 2007; Demain et al., 2009; Mahesh et al., 2008). However, not many reports are available on the antifungal properties of Apocynaceae family plants. In the present study, the distilled water extract, petroleum ether extract, methanolic extract, ethyl acetate extract and sequential distilled water leaf extracts of Catharanthus roseus, Nerium oleander and Tabernemontana divaricata showed activity against C. albicans ATCC 90028. Plant based products have been effectively proven for their utilization as a source for antimicrobial compounds.

In our study, various leaf extracts of C. roseus (Pink flower, White flower), N. oleander and T. divaricata were found to inhibit the growth in human fungal pathogen Candida albicans. The effect of various extracts was varying as per the plants. In Catharanthus roseus pink colour flower variety, petroleum ether and sequential distilled water extract most efficiently inhibited growth at $1 \mathrm{mg} / \mathrm{ml}$ whereas Petroleum ether was also the most effective Candida-cidal at $8 \mathrm{mg} / \mathrm{ml}$ (Table 1). In comparison various leaf extracts of $C$. roseus white flower variety, methanolic extract of leaf was inhibiting growth at $1 \mathrm{mg} / \mathrm{ml}$ and the most potential Candida cidal activity was exhibited by petroleum ether extract at $8 \mathrm{mg} / \mathrm{ml}$. White flower extract was found to be more effective than pink flower extract of C. roseus. As described in the previous studies the vinca alkaloid present in this plant is the active principle of anticancer drugs Vincristine and Vinblastin and it acts by disrupting microtubulin network in cell division process. This may be the probable reason why this extracts are inhibiting $C$. albicans growth at lower concentrations and viability at higher concentrations because C. albicans is an eukaryotic organisms having many similar targets as human cells (Cardenas et al., 1999).

$N$. oleander leaf extracts showed concentration dependent inhibition of growth. Ethyl acetate extract of leaf significantly inhibited growth of C. albicans at $1 \mathrm{mg} / \mathrm{ml}$
Table 1: MIC \& MFC values of plant extracts against $C$. albicans.

\begin{tabular}{cccc}
\hline Plant name & Extract name & $\begin{array}{c}\text { MIC } \\
(\mathbf{m g} / \mathbf{m l})\end{array}$ & $\begin{array}{c}\text { MFC } \\
(\mathbf{m g} / \mathbf{m l})\end{array}$ \\
\hline \multirow{4}{*}{$\begin{array}{c}\text { Catharanthus roseus } \\
\text { (Pink Flower) }\end{array}$} & Distilled water & 2 & 16 \\
& Petroleum ether & 1 & 8 \\
& Methanol & 4 & N/A \\
& Ethyl acetate & 4 & N/A \\
Catharanthus roseus & Dequistilled water & 2 & N/A \\
(White Flower) & Petroleum ether & 2 & 8 \\
& Methanol & 1 & 16 \\
& Ethyl acetate & 2 & N/A \\
& Sequential Distilled water & 2 & N/A \\
\hline & Distilled water & 2 & 16 \\
Nerium oleander & Petroleum ether & 4 & N/A \\
& Methanol & 2 & 8 \\
& Ethyl acetate & 1 & 16 \\
& Sequential Distilled water & 4 & 16 \\
\hline \multirow{4}{*}{ Tuberenemontanas } & Distilled water & 2 & N/A \\
divericata & Petroleum ether & 2 & N/A \\
& Methanol & 2 & N/A \\
& Ethyl acetate & 1 & N/A \\
& Sequential Distilled water & 4 & 16 \\
\hline N/A - Not Achieved & &
\end{tabular}

whereas it was cidal at $16 \mathrm{mg} / \mathrm{ml}$. Methanolic extract of leaf was the most efficient fungicidal killing all the cells at $8 \mathrm{mg} / \mathrm{ml}$. For this plant we could achieve MFC for four leaf extracts only excepting petroleum ether. Ethyl acetate extract of $T$. divaricata leaf was the most efficient growth inhibitor of C. albicans 90028 followed by petroleum ether and methanolic extracts and the sequential distilled water extract killed all the cells at $16 \mathrm{mg} / \mathrm{ml}$ proving to be the most efficient Candida-cidal.

Results of our in vitro study suggested a potential inhibitory effect of various leaf extracts of above mentioned plants against $C$. albicans growth and viability. These plants may be further investigated for their anti Candida properties under in vivo conditions. This may give insights into use of these plants belonging to Apocynaceae family for therapeutic purposes. $N$. oleander can be topically used in Candida infections such as skin or vaginal candidiasis. The results of present investigation clearly indicate that the antifungal activities vary with the species of the plants and plant material used. Thus, the study ascertains the value of Apocynaceae plants, which could be of considerable interest to the development of new antifungals.

\section{CONCLUSION}

Our present study demonstrates the antifungal potentialities of $C$. roseus, $N$. oleander and $T$. divaricata, which would improve our understanding to the biological role of the plant and future avenue to develop new pharmacological studies and antifungal therapies.

\section{ACKNOWLEDGEMENT}

Authors are thankful to Prof. S.B. Nimse, Honorable Vice chancellor, Swami Ramanand Teerth Marathwada University, Nanded for his support.

\section{REFERENCES}

Alviano, D. and Alviano, A. (2009). Plant extracts: search for new alternative to treat microbial diseases. Current Pharmaceutical Biotechnology, Volume 10, Pages106-121. [DOI]

Aslam, J. Khan, S.H. Siddiqui, Z.H. Fatima, Z. Maqsood, M. Bhat, M.A Nasim, S.A. Ilha, A. Ahmad, I.Z. Khan, S.A. Mujib, A. and Sharma, M.P. (2010). Catharanthus roseus (L.) G. Don. An important drug: its applications and production. International Journal of Comprehensive Pharmacy, Volume 4(12), Pages 1-16. 
Cardenas, M.E. Cruz, M.C. Del Poeta, M.Chung, N. Perfect, J.R. and Heitman, J. (1999) Antifungal activities of antineoplastic agents: Saccharomyces cerevisiae a model system to study drug action. Clinical Microbiology Reviews, Volume12 (4), Pages 583-611. [LINK]

Cordell, G. (2002). Natural products in drug discovery-creating a new vision, Phytochemistry Reviews, Volume 1 (3), Pages 261-273. [DOI]

Demain, A. L. and Sanchez, S. (2009) Microbial drug discovery : 80 years of progress; The Journal of Antibiotics, Volume 62, Pages 5-16. [DOI]

Eloff, J. (1998). Which extractant should be used for the screening and isolation of antimicrobial components from plants?, Journal of Ethnopharmacology, Volume 60, Pages 1-8. [DOI]

Ghosh, A. Das, B. Roy, A. Mandal, B. and Chandra, G. (2008). Antibacterial activity of some medicinal plant extracts. Journal of Natural Medicines, Volume 62, Pages 259-262. [DOI]

Itharat, A. andOoraikul, B.(2007). Research on Thai medicinal plants for cancer treatment. Advances in Medicinal Plant Research, Volume 2, Pages: 287-317.

Jaleel, C.A. Gopi, R. and Pannseerselvam, R.(2009). Alterations in nonenzymatic antioxidant components of Catharanthus roseus exposed to paclobutrazole, gibberellic acid and Pseudomonas fluorescens, Plant Omics, Volume 2 (1), Pages: 30-40.

Khan, M.S.A. (2011). Gastroprotective effect of Tabernaemontana divaricata (Linn.) R. Br. Flower methanolic extract in wistar rats. British journal of pharmaceutical research, Volume 1(3), Pages 88-98.

Lokesh, R. Leonard, B. E. Madhuri, P.Saurav, K. andSundar, K.(2010) Larvicidal activity of Trigonella foenum and Nerium oleander leaves against mosquito larvae found in Vellore city. Current Research Journal of Biological Sciences, Volume 2(3), Pages154-160.

Mahesh, B. Satish, S. (2008). Antimicrobial activity of some important medicinal plant against plant and human pathogens. World journal of agricultural sciences, Volume 4(S), Pages 839-843.

Mukherjee, A. Basu, S. Sarkar, N. and Ghosh, A. (2001). Advances in cancer therapy with plant based natural products, Current medicinal chemistry, Volume 8, Pages 1467-1486. [DOI]

Naik, V.N. (1998). Flora of Marathwada. 2nd ed. Amrut Prakashan, Station Road, Aurangabad, India.

Newman, D. and Cragg, G. M. (2007). Natural products as sources of new drugs over the last 25 years, Journal of natural products, Volume 70 (3) Pages 461-477. [DOI] PMid:17309302
Pfaller, M.A. and Diekema, D.J. (2007). Epidemiology of invasive candidiasis: a persistent public health problem. Clinical Microbiology Reviews Volume 20, Pages133-163. [DOI]

Pratchayasakul, W., Pongchaidecha, A. Chattipakorn, N. and Chattipakorn, S. (2008). Ethnobotany \& ethnopharmacology of Tabernaemontana divaricata. Indian Journal of Medicinal Research, Volume 127, Pages 317-335. PMid: 18577786.

Quiroga, E. Sampietro, A. andVattuone, A. (2001). Screening antifungal activities of selected medicinal plants, Journal of Ethnopharmacology, Volume 74, Pages 89-96. [DOI]

Raskin, I. Ribnicky, D. Komarnytsky, S. Ilic, N. Poulev, A. Borisjuk, N. Brinker, A. Moreno, A. Ripoll, C. Yakoby, N. Cornwell, T. Pastor, I. andFridlender, B. (2002). Plants and human health in the twenty-first century, Trends in Biotechnology, Volume 20 (12), Pages 522-531. [DOI]

Routh, M.M., Raut, J.S. and Karuppayil, S.M.(2011). Dual properties of anticancer agents: An exploratory study on the in vitro anti-Candida properties of thirty drugs. Chemotherapy. Volume 57, Pages 372-380. [DOI]

Rumzhum, N.N. Rahman M.M. Kazal, M.K. (2012). Antioxidant and cytotoxic potential of methanol extract of Tabernaemontana divericata leaves. International current pharmateutical journal, Volume 1(2), Pages 27-31. [DOI]

Sakarkar, D. andDeshmukh, V. (2011). Ethnopharmacological review of traditional medicinal plants for anticancer activity. International Journal of Pharma Tech Research, Volume 3, Pages 298-308.

Santhi, R., Lakshmi, G., Priyadarshini, A. M. and Anandaraj, L. (2011). Phytochemical screening of Nerium oleander Linn. leaves and Momordica charantia leaves. International research journal of pharmacy, Volume 2(1), Pages 131-135.

Singhal, K.G. and Gupta, G.D. (2011). Some Central Nervous System Activities of Nerium Oleander Linn (Kaner) Flower Extract. Tropical Journal of Pharmaceutical Research, Volume 10 (4), Pages 455-461.ss [DOI]

Verpoorte, R. (2000). Pharmacognosy in the new millenium: lead finding and biotechnology. Journal of Pharmacy and Pharmacoloy, Volume 52 Pages 253-262. [DOI] 